\title{
Properties and characterization of CZTS nanoparticles prepared by microwave heating irradiation
}

\author{
Giedrè Grinciene் ${ }^{*}$ \\ Vidas Pakštas, \\ Raimondas Giraitis, \\ Gediminas Niaura, \\ Arnas Naujokaitis, \\ Jurga Juodkazyte், \\ Loreta Tamašauskaitè-Tamašiūnaitè, \\ Remigijus Juškẻnas, \\ Birutè Šimkūnaitè-Stanynienè, \\ Eugenijus Norkus \\ Center for Physical Sciences and Technology, \\ Sauletekio Ave. 3, 10257 Vilnius, Lithuania
}

\begin{abstract}
$\mathrm{Cu}_{2} \mathrm{ZnSnS}_{4}$ (CZTS) nanoparticles suitable for solar cell absorber fabrication were synthesized by the microwave-assisted heating method. The influence of the reaction temperature, the temperature increase duration and post-annealing temperature on the chemical composition, crystallographic structure, phase purity and optical properties of CZTS nanocrystals has been investigated by means of XRD, Raman spectroscopy, scanning (SEM) and transmission electron microscopies (TEM), EDX and UV-Vis spectroscopies. The chemical composition of the CZTS nanoparticles synthesized at a temperature of $250^{\circ} \mathrm{C}$ and the temperature increase duration of $10 \mathrm{~min}$ are almost stoichiometric. The post-annealing process of CZTS has been investigated by means of the in situ XRD method. The results obtained point to the presence of a pure CZTS phase after annealing of the synthesized powder at a temperature of $550^{\circ} \mathrm{C}$. The direct band gap energy $\left(E_{g}\right)$ of the CZTS nanoparticles obtained depends on the post-annealing temperature and reaches nearly $1.5 \mathrm{eV}$ at $550^{\circ} \mathrm{C}$.
\end{abstract}

Keywords: $\mathrm{Cu}_{2} \mathrm{ZnSnS}_{4}$ (CZTS) nanoparticles, microwave synthesis, XRD in situ

\section{INTRODUCTION}

A steady growth of energy needs and decreasing availability of fossil fuels make scientific community concerned about alternative and renewable energy sources. Though costly to implement, solar energy is one of such solutions.

For years researchers have been working on the development of different types of solar cells trying to reach higher power conversion efficiency (PCE). Thin film solar cells with CdTe, CuInGaSe ${ }_{2}$ (CIGS) or $\mathrm{CuInSe}_{2}$ (CIS) absorber layers have already reached rather high PCE (over 20\%) [1]. However, these layers contain In (indium) and Ga (gallium), which are expensive and scarce in Earth's crust or

\footnotetext{
* Corresponding author. Email: giedre.grinciene@ftmc.lt
}

toxic like $\mathrm{Cd}$ (cadmium). The $\mathrm{Cu}_{2} \mathrm{ZnSnS}_{4}$ (CZTS) composed of earth-abundant, inexpensive and non-toxic components could be used as an alternative to the above-mentioned absorber layers. The CZTS has similar optical and photoelectric characteristics: a band gap of $1.5 \mathrm{eV}$ and a relatively high light absorption coefficient $10^{4} \mathrm{~cm}^{-1}$ [2]. The CZTS solar cell fabricated using the hydrazine solvent method showed a great result yielding PCE higher than 12\% [3-6]; however, hydrazine is very toxic and cannot be widely used. Researchers continue searching for non-toxic solutions methods for fabrication of solar cells.

Different vacuum and non-vacuum methods on the synthesis of CZTS nanoparticles have been reported in the literature. The record efficiency for electrodeposited CZTS reached 8.0\% [7-8], DC magnetron sputtering deposition [9] 
(efficiency for CZTS solar cells - 10.4\%) [10-11], spray pyrolysis deposition [12], sol-gel [13], the ink-print method with a conversion efficiency of 7.2\% [14], mechanochemical [15], solvothermal [16] and so on.

Microwave irradiation (MW) is a technique for the controlled synthesis of various nanomaterials due to its distinct advantages like homogeneous nucleation, high reproducibility, better particles size control, good purity and shorter crystallization time [17]. While the mechanochemical and solvothermal methods for CZTS nanoparticle synthesis take a long time to complete and hot injection synthesis is hard to control.

Synthesis of CZTS nanoparticles with a size of $7.6 \pm 2.1 \mathrm{~nm}$ by means of the MW approach was first reported by Flynn et al. in 2012 [18]. Wang et al. proposed a facile and simple technique for one-pot $\mathrm{Cu}_{2} \mathrm{ZnSnS}_{4}$ synthesis followed by annealing in a glove box of sulphur atmosphere [19]. Two-step synthesis of CZTS from aqueous solutions by microwave irradiation and sulphurization was presented by Shin et al. [20]. It was determined that CZTS, synthesized in ethylene glycol by the MW method, has an optical band gap of $1.76 \mathrm{eV}$ [21]. The influence of reaction time and temperature on the structure, morphology and optical properties of the prepared CZTS was also investigated in Refs. [22-25]. The impact of sulphur sources on the morphology and size of CZTS nanoparticles was researched by Wang [26]. Chen et al. studied the influences of the reaction temperature on the chemical composition and purity of nanocrystals [27-28]. Doughnut-shaped CZTS microparticles were synthesized by cyclic MW using $\mathrm{N}, \mathrm{N}$-dimethylformamide and polyvinylpyrolidone as a solvent and a stabilizing agent [29]. The influence of thiourea concentration on the formation of CZTS was investigated in Ref. [30], and that of reaction temperature and duration on the phase purity in Refs. [31-32].

In the current work the MW synthesis of CZTS nanoparticles, which could further be used for fabrication of an absorber layer for thin solar cells, was studied. The impact of synthesis temperature, the temperature increase rate, postannealing temperature of as-synthesised CZTS nanoparticles on the chemical composition, crystalline structure, phase purity and band gap was examined. For the first time the impact of the temperature increase rate and dependency of the band gap on the crystallites size were shown. The CZTS formation reaction at different temperatures was studied by the XRD in situ method.

\section{EXPERIMENTAL}

\section{Synthesis of CZTS nanoparticles}

The precursor solution was prepared using $0.1 \mathrm{M}$ copper chloride $\left(\mathrm{CuCl}_{2}\right), 0.05 \mathrm{M}$ zinc chloride $\left(\mathrm{ZnCl}_{2}\right), 0.05 \mathrm{M}$ tin chloride $\left(\mathrm{SnCl}_{2}\right)$ and $0.4 \mathrm{M}$ thiourea $\left(\mathrm{SC}\left(\mathrm{NH}_{2}\right)_{2}\right)$. All chemicals were of analytical grade and used without further purification. In a typical procedure metal chlorides were dissolved in a $20 \mathrm{ml}$ ethylene glycol-water (70\% ethylene glycol and 30\% water) mixture at room temperature under stirring. The prepared reaction solution was put into a microwave reactor Monowave 300 (Anton Paar) and synthesis was carried out at constant temperatures of 150, 180, 200, 220 and $250^{\circ} \mathrm{C}$ for $60 \mathrm{~min}$. The product synthesized was washed with acetone and ultra-pure water, then filtered and dried in a vacuum oven at a temperature of $80^{\circ} \mathrm{C}$ for $2 \mathrm{~h}$. Finally, the precursor powder obtained was annealed at different temperatures for $2 \mathrm{~h}$ in sealed glass ampoules (volume of about $3 \mathrm{~cm}^{3}$ ) either with addition of sulphur (3 weight \%) or without it.

\section{Characterization}

XRD patterns of studied powders were measured using an X-ray diffractometer SmartLab (Rigaku) equipped with an $\mathrm{X}$-ray tube with a $9 \mathrm{~kW}$ rotating $\mathrm{Cu}$ anode. The measurements were performed using Bragg-Brentano geometry with a graphite monochromator on the diffracted beam and a step scan mode with a step size of $0.02^{\circ}$ (in $2 \theta$ scale) and counting time of $1 \mathrm{~s}$ per step. The measurements were conducted in the $2 \theta$ range of $10-70^{\circ}$. High temperature XRD in situ measurements were conducted in helium atmosphere using a high temperature stage DHS 1100 (Anton Paar). Phase identification was performed using the software package PDXL (Rigaku) and the ICDD powder diffraction database PDF4+ (2015 release). The size of crystallites was calculated from XRD peaks broadening using the graphical Halder-Wagner method implemented in the PDXL software.

The Raman spectra of synthesized powders were recorded using an inVia (Renishaw) spectrometer equipped with a thermoelectrically cooled $\left(-70^{\circ} \mathrm{C}\right) \mathrm{CCD}$ camera and a microscope. The $532 \mathrm{~nm}(2.33 \mathrm{eV})$ beam of the solid state laser was used as an excitation source. The Raman scattering wavenumber axis was calibrated by the silicon peak at $520.7 \mathrm{~nm}$. The $50 \times / 0.75$ objective was used during the measurements. To avoid damage of the sample, the laser power was restricted to $0.06 \mathrm{~mW}$. Parameters of the bands were determined by fitting the experimental spectra with Gaussian-Lorentzian shape components using the GRAMS/ A1 8.0 (Thermo Scientific) software.

The morphology and composition of the thin CZTS layers deposited on glassy carbon were characterized using a SEM/FIB workstation Helios Nanolab 650 with an energy dispersive X-ray (EDX) spectrometer INCA Energy 350 XMax 20. The images of particles were taken in a transmission electron microscope (TEM) Tecnai G2 F20 X-TWIN (FEI, Netherlands) equipped with an EDX spectrometer with an r-TEM detector. For microscopic examination, $15 \mathrm{mg}$ of the synthesized powder was first sonicated in $2 \mathrm{ml}$ of ethanol for $30 \mathrm{~min}$. Then, $10 \mu \mathrm{l}$ of prepared CZTS slurries were deposited on the surface of glassy carbon.

Absorption spectra were recorded using a UV-Vis spectrometer (Perkin Elmer, Lambda 35). The same amount of 
CZTS slurries was taken as in the microscopic examination and deposited on the glass sheet.

Photoelectrochemical behaviour was examined by immersion of the CZTS samples deposited on the ITO surface into a glass cuvette with a solution of $0.5 \mathrm{M} \mathrm{Na}_{2} \mathrm{SO}_{4}$ and measuring the open-circuit potential $\left(E_{o c}\right)$ values under illumination using a potentiostat/galvanostat AUTOLAB 302. The $\mathrm{Ag} / \mathrm{AgCl} /$ sat. $\mathrm{KCl}$ electrode was used as a reference electrode. The surface of CZTS samples was illuminated with a high intensity discharge Xe-lamp with the $6000 \mathrm{~K}$ spectrum and calibrated with a silicon diode to simulate AM 1.5 illumination $\left(\sim 100 \mathrm{~mW} \mathrm{~cm}^{-2}\right)$ at the sample surface. Back sides of both electrodes were isolated from the contact with an electrolyte with PVC lacquer in order to exclude the contribution of reflected light. The amount of CZTS on the ITO surface was $1 \mathrm{mg} / \mathrm{cm}^{2}$.

\section{RESULTS AND DISCUSSION}

The characterization of the CZTS nanoparticles synthesized at different reaction temperatures has shown that the temperature of the reaction mixture is one of the most important factors for the growth of CZTS nanoparticles of the desired chemical composition. It has been found that the sulphides of single metals convert into CZTS and grow as a high purity CZTS phase at a higher temperature of synthesis as described in Ref. [22]. Herein, the CZTS powders were synthesized at different temperatures. The results of the EDX analysis of prepared samples are given in Table 1. According to the data obtained, the composition of as-synthesized CZTS powder was nearly stoichiometric when the temperature of the reaction mixture was kept at a temperature of $250^{\circ} \mathrm{C}$ (Table 1 ).

Another important parameter of the microwave assisted synthesis of CZTS is a rate of temperature increase or temperature increase duration. Figure 1 presents the dependences of compositional ratios $\mathrm{Zn} / \mathrm{Sn}, \mathrm{Cu} /(\mathrm{Zn}+\mathrm{Sn}), \mathrm{Cu} / \mathrm{Sn}$, and $(\mathrm{Cu}+\mathrm{Zn}+\mathrm{Sn}) / \mathrm{S}$ on time during which the temperature of $250^{\circ} \mathrm{C}$ is reached. As seen, when the temperature of $250^{\circ} \mathrm{C}$ is reached after $10 \mathrm{~min}$, the chemical composition of CZTS nanoparticles is nearly stoichiometric. When the temperature was elevated at a slower rate, a relative increase in copper and decrease in tin were obtained.

The influence of annealing temperature on the purity, crystallographic structure and composition of the CZTS

Table 1. The chemical composition ratio of CZTS particles after synthesis at different temperatures

\begin{tabular}{c|c|c|c|c|c|c|c}
\hline \multirow{2}{*}{ Temp., C } & \multicolumn{4}{c|}{ Chemical composition, at.\% } & \multicolumn{3}{c}{ Composition ratios } \\
\cline { 2 - 8 } & Cu & Zn & Sn & S & Cu/(Zn+Sn) & Zn/Sn & S/(Cu+Zn+Sn) \\
\hline 150 & 24.92 & 9.8 & 13.25 & 52.04 & 1.08 & 0.74 & 0.94 \\
\hline 180 & 22.8 & 10.48 & 13.84 & 52.88 & 1.09 & 1.12 \\
\hline 200 & 21.56 & 12.6 & 11.36 & 54.48 & 0.90 & 1.20 \\
\hline 250 & 23.32 & 12.74 & 11.12 & 52.82 & 0.98 & 1.15 \\
\hline
\end{tabular}

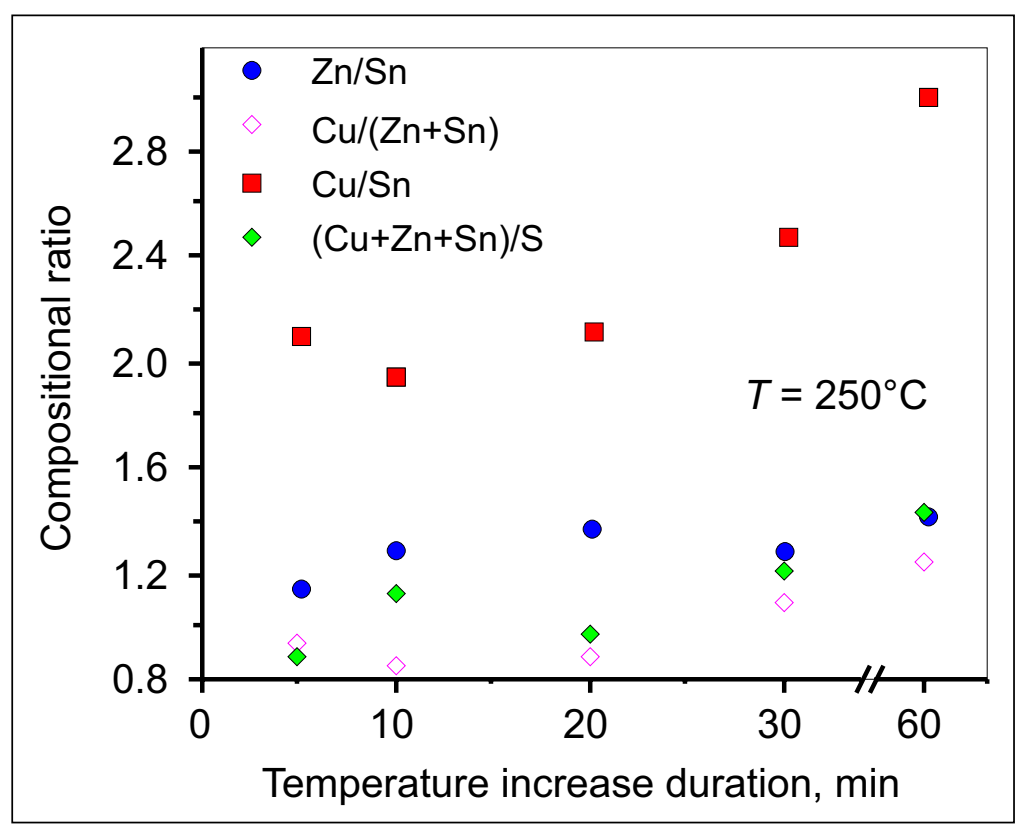

Fig. 1. Dependences of compositional ratios $Z n / S n, C u /(Z n+S n), C u / S n$, and $(C u+Z n+S n) / S$ on the duration of temperature elevation up to $250^{\circ} \mathrm{C}$ 
nanocrystals synthesized at a temperature of $250^{\circ} \mathrm{C}$ has also been investigated. Usually, the thermal annealing is carried out with addition of sulphur or sometimes tin to prevent the decomposition of $\mathrm{Cu}_{2} \mathrm{ZnSnS}_{4}$ [33]. Figure 2 shows the XRD patterns of CZTS nanocrystals annealed at a temperature of $550^{\circ} \mathrm{C}$ for $1 \mathrm{~h}$ in a glass ampoule (sealed after partial air removal by heating) without sulphur (1) and with addition of sulphur (3 weight \%) (2). Both of the XRD patterns reveal the same phase composition, namely $\mathrm{Cu}_{2} \mathrm{ZnSnS}_{4}$ (ICDD \# 00-026-0575) and hexagonal ZnS (ICDD \# 04-008-7254). Next, the CZTS nanoparticles powder, synthesized at a temperature of $250^{\circ} \mathrm{C}$, was annealed in $\mathrm{Ar}(95 \%)+\mathrm{H}_{2}(5 \%)$ atmosphere at different temperatures $450,500,525$ and $550^{\circ} \mathrm{C}$ without addition of sulphur. The chemical compositions of the CZTS powders annealed are given in Table 2. As seen, the annealing temperature has no significant impact on the chemical composition while heating with sulphur. However, the atomic ratios of elements changed after the annealing of CZTS powder without addition of sulphur. The values of $\mathrm{Cu} /(\mathrm{Zn}+\mathrm{Sn}), \mathrm{Zn} / \mathrm{Sn}$ and $\mathrm{S} /(\mathrm{Cu}+\mathrm{Zn}+\mathrm{Sn})$ ratios decreased after the annealing at a temperature of $550^{\circ} \mathrm{C}$, especially the values of the latter two ratios (Table 2). This result could indicate that CZTS lost some $\mathrm{ZnS}$ during the annealing process. The XRD patterns of the annealed CZTS powder reveal a decrease in the breadth of the XRD peaks with increase in temperature, but there were no visible changes in the phase composition (Fig. 3).

The comparison of the SEM images of as-synthesized CZTS powder and that after annealing at a temperature of $550^{\circ} \mathrm{C}$ shows that there is no significant difference between the grain sizes of both powders (Fig. A). In both the cases, the powder grains present spherical agglomerates (200$500 \mathrm{~nm}$ in diameter) of nanocrystals. This was confirmed by TEM images of the grains (Fig. 5). The grains are composed of crystallites sized ca. $20-40 \mathrm{~nm}$.

The size of the crystallites was also determined using the XRD patterns by the Halder-Wagner method. While increasing the annealing temperature from 300 to $550^{\circ} \mathrm{C}$, the size of crystallites increases from 2.4 to $24.1 \mathrm{~nm}$,

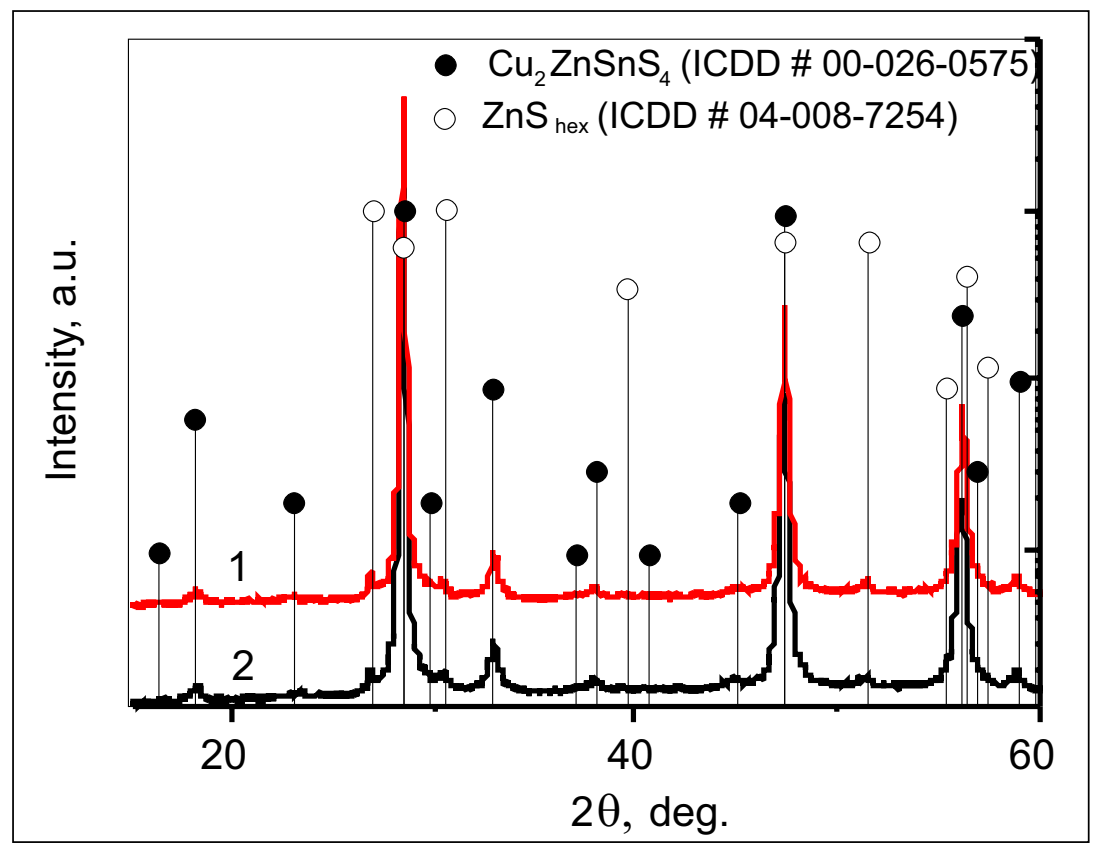

Fig. 2. XRD patterns of the CZTS powdery precursor annealed at temperature of $550^{\circ} \mathrm{C}$ for $1 \mathrm{~h}$ in glass ampoules without sulfur (1) and with addition of (3 weight \%) sulfur (2)

Table 2. The chemical composition and elements ratio of CZTS powders after their annealing at different temperatures without addition of sulphur

\begin{tabular}{|c|c|c|c|c|c|c|c|}
\hline \multirow{2}{*}{ Annealing temp., ${ }^{\circ} \mathrm{C}$} & \multicolumn{4}{|c|}{ Chemical composition, \% } & \multicolumn{3}{|c|}{ Composition ratio, $\%$} \\
\hline & Cu & $\mathrm{Zn}$ & Sn & $s$ & $\mathrm{Cu} /(\mathrm{Zn}+\mathrm{Sn})$ & $\mathrm{Zn} / \mathrm{Sn}$ & $S /(C u+Z n+S n)$ \\
\hline Without anneal. & 23.32 & 12.74 & 11.12 & 52.82 & 0.98 & 1.15 & 1.12 \\
\hline 400 & 23.84 & 13.05 & 12.4 & 50.71 & 0.94 & 1.05 & 1.03 \\
\hline 500 & 23.65 & 12.85 & 12.54 & 50.97 & 0.93 & 1.02 & 1.04 \\
\hline 550 & 23.87 & 13.31 & 12.54 & 50.28 & 0.92 & 1.06 & 1.01 \\
\hline
\end{tabular}




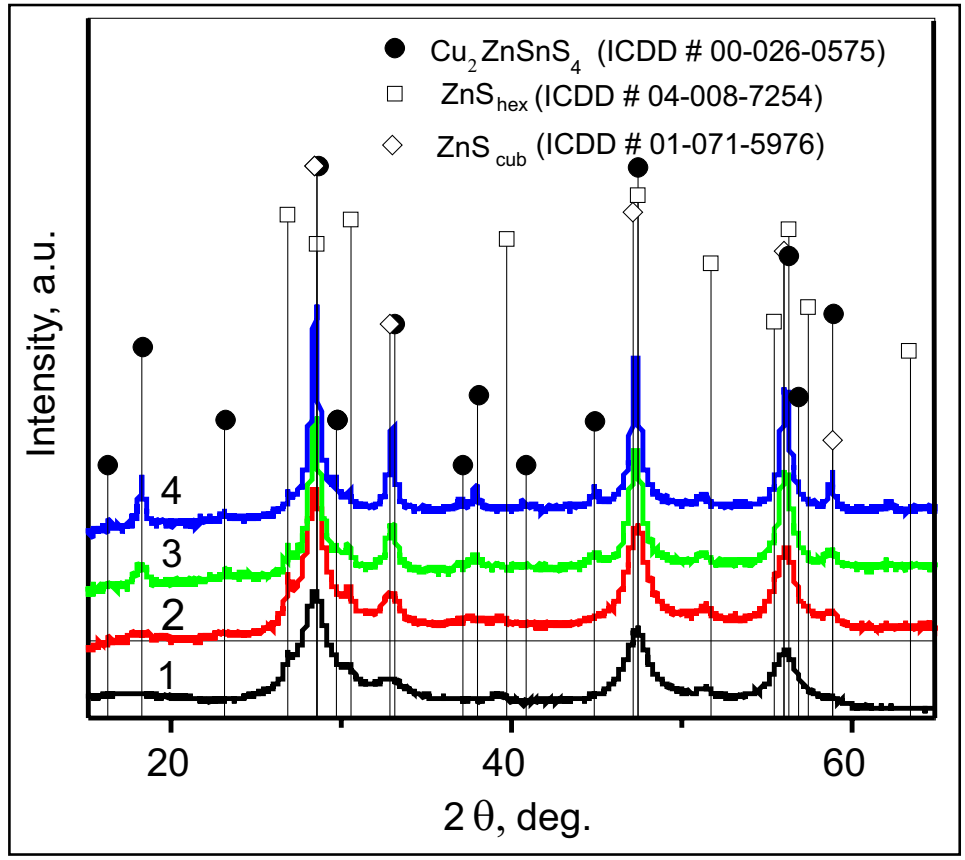

Fig. 3. XRD patterns of the CZTS precursor material annealed in glass ampoules for $2 \mathrm{~h}$ at different temperatures: as-synthesized (1), $400(2) ; 500(3) ; 550^{\circ} \mathrm{C}(4)$

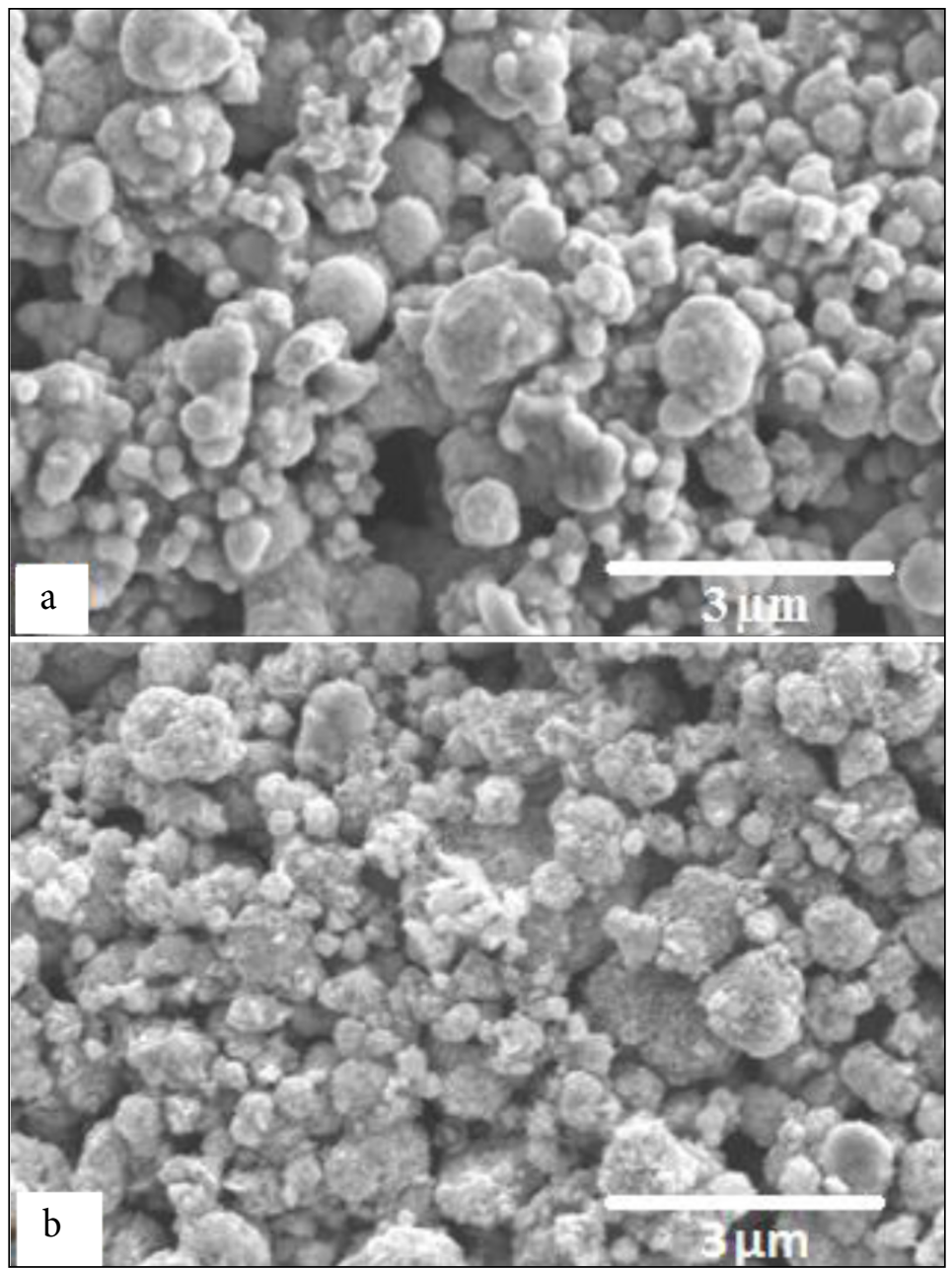

Fig. 4. The SEM images of as-synthesized CZTS nanocrystals (a) and annealed at $550^{\circ} \mathrm{C}$ (b) 


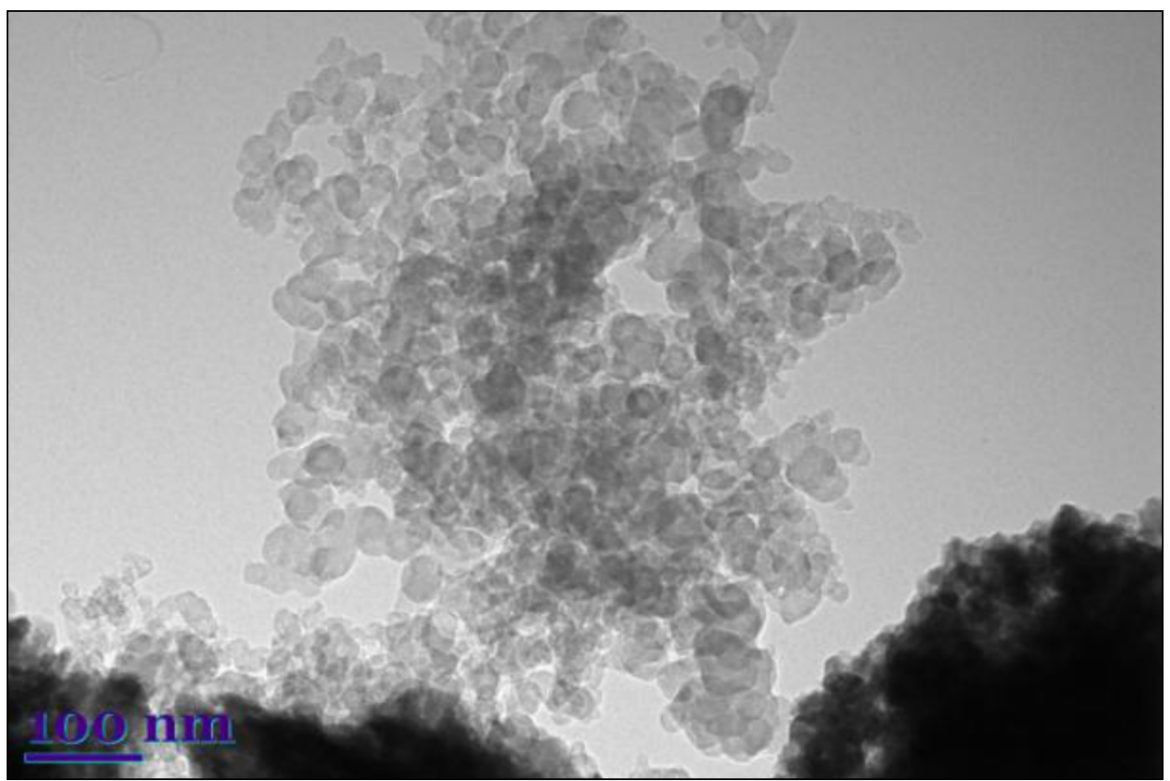

Fig. 5. The bright-field TEM image of CZTS nanoparticles, prepared by MW synthesis and annealed at $550^{\circ} \mathrm{C}$

respectively (Table 3). This is in a rather good agreement with the results obtained by the TEM analysis.

Table 3. The size of kesterite crystallites after annealing of CZTS powders in glass ampoules at different temperatures

\begin{tabular}{cc}
\hline Annealing temp., ${ }^{\circ} \mathbf{C}$ & Particle size by XRD, nm \\
\hline Without annealing & $\sim 1$ \\
\hline 300 & $2.4 \pm 0.3$ \\
\hline 400 & $4.3 \pm 0.4$ \\
\hline 500 & $13.2 \pm 0.3$ \\
\hline 550 & $24.1 \pm 0.4$ \\
\hline
\end{tabular}

The most intensive XRD peaks of $\mathrm{Cu}_{2} \mathrm{ZnSnS}_{4}, \mathrm{Cu}_{3} \mathrm{SnS}_{4}$, $\mathrm{Cu}_{2} \mathrm{SnS}_{3}$, and $\mathrm{ZnS}$ are very close to each ather and the differences in the diffraction angles are within instrumental accuracy. The evaluation of $\mathrm{Cu}_{2} \mathrm{ZnSnS}_{4}$ purity solely on the basis of the XRD pattern is not sufficient. Therefore, for further confirmation of the formation of the pure CZTS phase, the Raman spectrum of the as-synthesized solid sample was recorded due to the ability of this technique to distinguish between the $\mathrm{Cu}_{2} \mathrm{ZnSnS}_{4}\left(336 \mathrm{~cm}^{-1}\right)$, $\mathrm{ZnS}\left(351\right.$ and $\left.274 \mathrm{~cm}^{-1}\right), \mathrm{Cu}_{3} \mathrm{SnS}_{4}\left(318,348\right.$, and $\left.295 \mathrm{~cm}^{-1}\right)$, $\mathrm{Cu}_{2} \mathrm{SnS}_{3}\left(363 \mathrm{~cm}^{-1}\right)$ and $\mathrm{Cu}_{2-\mathrm{x}} \mathrm{S}\left(473 \mathrm{~cm}^{-1}\right)$ phases. Figure 6 a compares the Raman spectra in a frequency region of $60-1800 \mathrm{~cm}^{-1}$ of the CZTS samples annealed at different temperatures. A broad doublet near 1354-1404 and 1564$1597 \mathrm{~cm}^{-1}$ is associated with bands D and G of disordered carbon, respectively [34]. A relatively narrow peak near $336 \mathrm{~cm}^{-1}$ belongs to the symmetry band $\mathrm{A}$ of the $\mathrm{Cu}_{2} \mathrm{ZnSnS}_{4}$ (CZTS) compound [35-37]. This mode implies movement of the sulphur atoms only [36]. Several components of lower intensity are visible in a frequency region of $200-430 \mathrm{~cm}^{-1}$ (Fig. 6b). Decomposition of the experimental contour into the Lorentzian-Gaussian form component yields bands near 290 and $363 \mathrm{~cm}^{-1}$. Both the bands are associated with the vibrations of the CZTS compound however, there can be some contribution from the $\mathrm{Cu}_{2} \mathrm{SnS}_{3}$ compound as well [35, 38]. A broad band near $665 \mathrm{~cm}^{-1}$ is due to the second-order vibration of CZTS [39]. No spectroscopic evidence of the $\mathrm{Cu}_{2-\mathrm{x}} \mathrm{S}$ phase (band near $473 \mathrm{~cm}^{-1}$ ) was obtained [40]. The influence of annealing temperature on the degree of crystallinity of the CZTS phase can be analysed by comparing the full width at half maximum (FWHM) of the most intense $\mathrm{Cu}_{2} \mathrm{ZnSnS}_{4}$ band of different samples (Table 4). Clearly, an increase in annealing temperature results in narrowing bands; thus the degree of crystallinity increases. As the $363 \mathrm{~cm}^{-1}$ band may have some contribution from the secondary phase $\mathrm{Cu}_{2} \mathrm{SnS}_{3}$, we have compared the relative intensity ratio $I_{336} / I_{363}$. One can see that annealing of the prepared powder at a temperature of $550^{\circ} \mathrm{C}$ results in a slight increase in the ratio, probably, because of the occurrence of a purer CZTS phase (Table 4).

Ta ble 4. Parameters of the CZTS Raman band near $336 \mathrm{~cm}^{-1}$

\begin{tabular}{c|c|c|c}
\hline $\begin{array}{c}\text { Annealing } \\
\text { temp., }{ }^{\circ} \mathbf{C}\end{array}$ & Peak position, $\mathbf{~ c m}^{-1}$ & FWHM, $\mathbf{~ c m}^{-1}$ & $\begin{array}{c}\text { Relative int. } \\
\mathbf{I 3 3 6 / 1 3 6 3}\end{array}$ \\
\hline 400 & 335.4 & 20.9 & 6.0 \\
\hline 500 & 336.1 & 14.4 & 5.6 \\
\hline 550 & 335.7 & 13.9 & 6.9 \\
\hline
\end{tabular}

In attempting to explain the reactions which took place during the thermal annealing of as-synthesised nanocrystals, high temperature XRD in situ measurements were conducted. The phase composition of CZTS powder was examined 


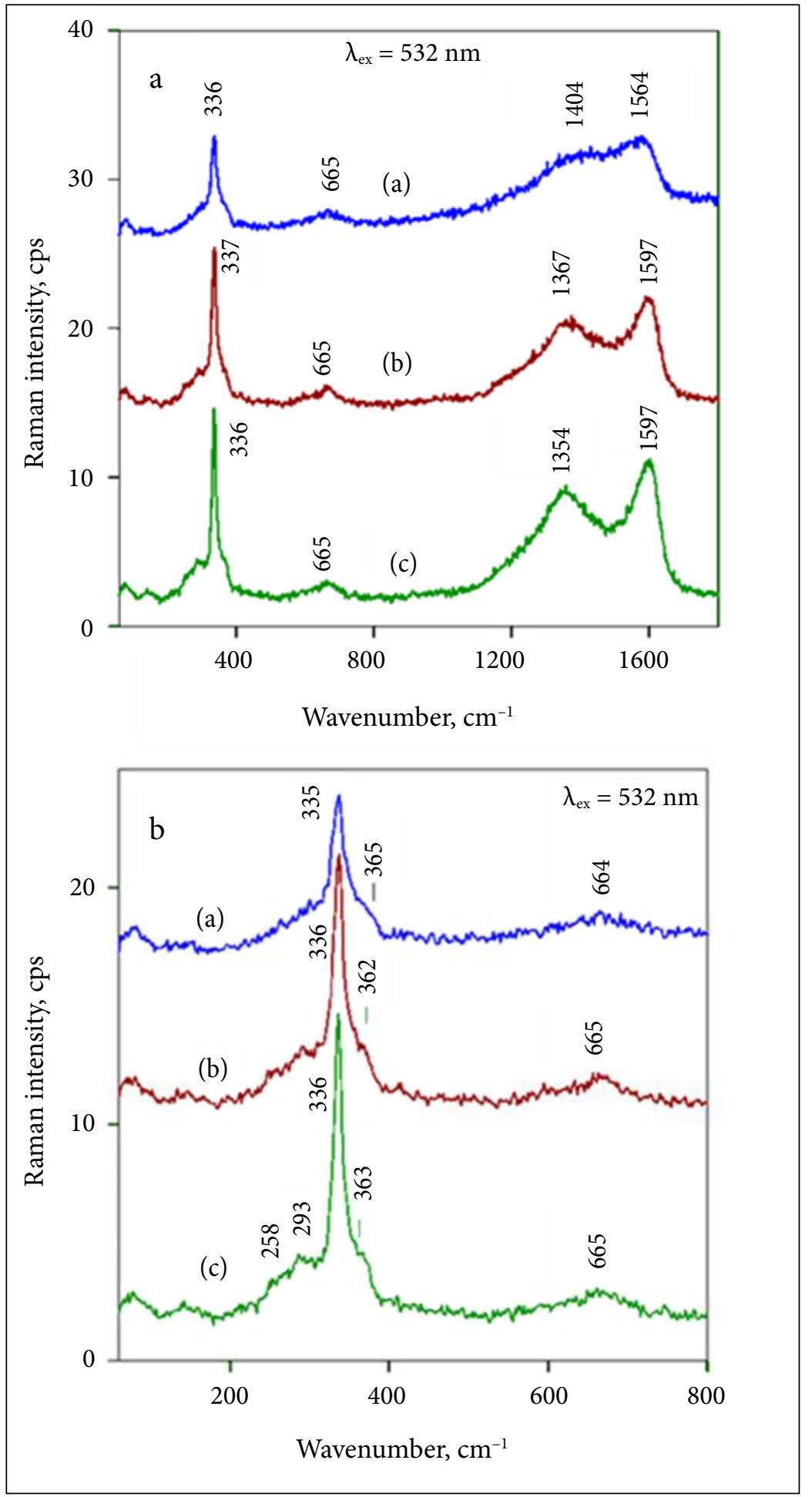

Fig. 6. The Raman spectrum of synthesized CZTS compounds (in the powder form) annealed at temperatures ( $\left.{ }^{\circ} \mathrm{C}\right)$ : 400 (a), 500 (b) and 550 (c) in the spectral region of $60-1800 \mathrm{~cm}^{-1}(\mathrm{a}), 60-800 \mathrm{~cm}^{-1}(\mathrm{~b})$. The excitation wavelength is $532 \mathrm{~nm}(0.06 \mathrm{~mW})$

during annealing of the as-synthesised powder under an inert atmosphere of helium at different temperatures. For this purpose, the as-synthesized CZTS powder was pressed into tablets of ca. $1 \mathrm{~mm}$ in thickness and $10 \mathrm{~mm}$ in diameter. The tablets were heated under helium atmosphere at temperatures of $450,500,525$ and $550^{\circ} \mathrm{C}$. After reaching the de- sired value, the temperature was maintained for $10 \mathrm{~min}$ and then the XRD pattern was recorded at the same temperature. The conducted XRD in situ studies have shown that the assynthesized CZTS precursor powder consists of a mixture of monoclinic $\mathrm{Cu}_{2} \mathrm{SnS}_{3}$ (ICDD \# 04-010-5719), ZnS with a cubic (ICDD \# 01-071-5976) and a hexagonal structure 
(ICDD \# 04-008-7254). When the annealing temperature was increased up to $450^{\circ} \mathrm{C}$, XRD peaks characteristic of $\mathrm{Cu}_{2} \mathrm{ZnSnS}_{4}$ (ICDD \# 00-026-0575) emerged at $2 \theta$ angles of 16.06 and $18.21^{\circ}$ and XRD peaks of $\mathrm{Cu}_{2} \mathrm{SnS}_{3}$ and $\mathrm{ZnS}$ phases started to decrease. Metastable hexagonal $\mathrm{ZnS}$ dissociated at temperatures above $450^{\circ} \mathrm{C}$ in the flow of helium gas and the XRD peaks at $2 \theta=26.91$ and $30.52^{\circ}$ vanished (Fig. 7).
While conducting the high temperature XRD in situ studies of the $\mathrm{Cu}_{2} \mathrm{ZnSnS}_{4}$ precursor at a temperature of $550^{\circ} \mathrm{C}$, it was noticed that the XRD peak -111 of the $\mathrm{Cu}_{2} \mathrm{SnS}_{3}$ phase was constantly shifting to higher diffraction angles and after 120 min matched with the $2 \theta$ position of XRD peak 101 of the $\mathrm{Cu}_{2} \mathrm{ZnSnS}_{4}$ phase (Fig. 8). This should mean that at a temperature of $550^{\circ} \mathrm{C}$ about $120 \mathrm{~min}$ is required to trans-

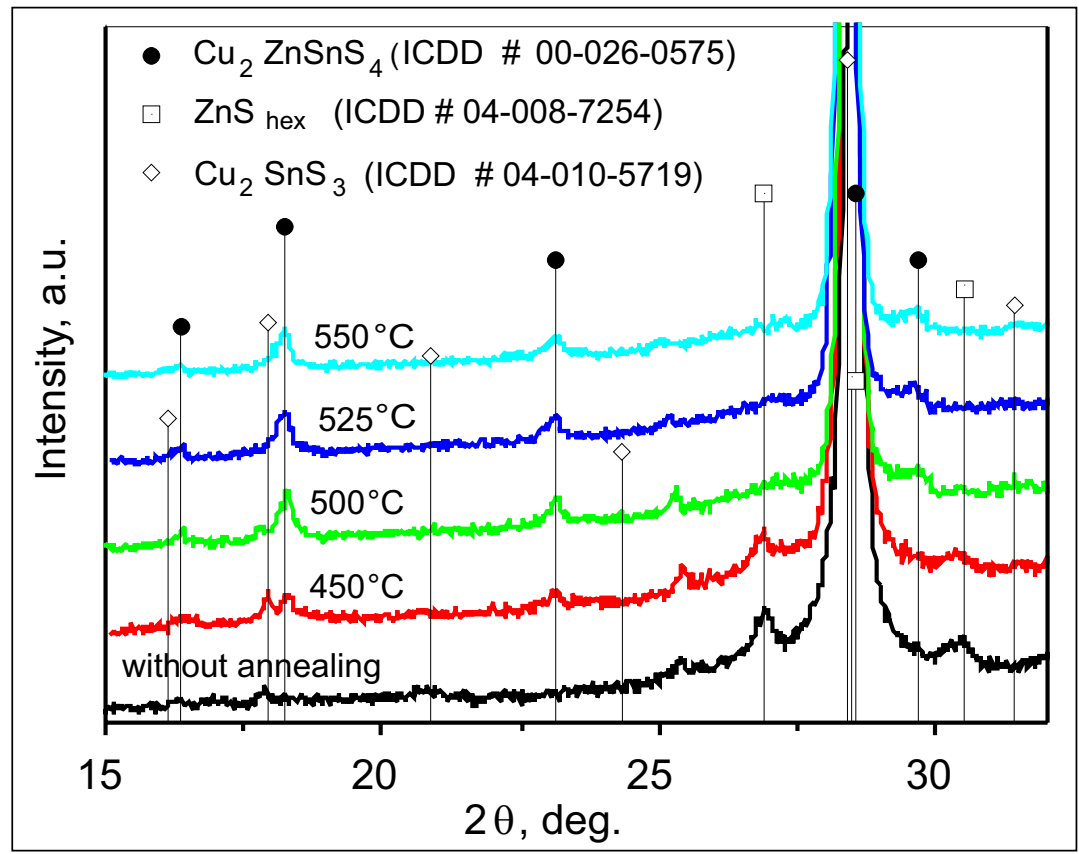

Fig. 7. XRD patterns of the CZTS precursor tablet measured using the high temperature XRD in situ technique at different temperatures. The XRD patterns $2 \theta$ scales were corrected considering thermal expansion of the specimen

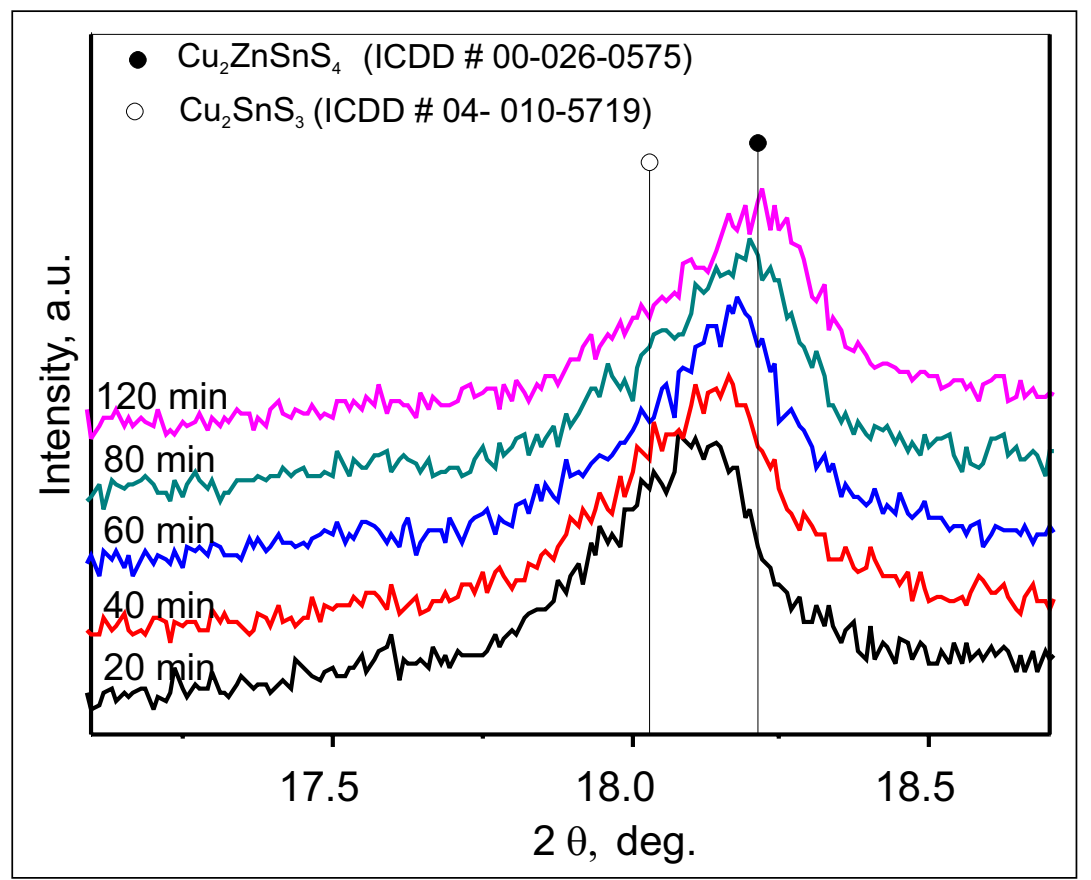

Fig. 8. Change in the XRD peak $\mathrm{Cu}_{2} \mathrm{SnS}_{3}-111$ position during high temperature XRD in situ measurements at a temperature of $550^{\circ} \mathrm{C}$ 
form the CZTS precursor, obtained by microwave synthesis, into a nearly pure $\mathrm{Cu}_{2} \mathrm{ZnSnS}_{4}$ phase according to the Raman spectroscopy results.

The properties of the as-synthesized CZTS nanocrystals annealed at different temperatures were also investigated by means of UV/Vis spectroscopy. The absorption spectra of the thin layers of CZTS nanoparticles annealed at different temperatures are shown in Fig. 9a. The size and phase composition of CZTS nanoparticles were different, which might lead to differences in light absorbtion. Maybe, that was the reason for the different shape of absorption curves.
The band gap energies were obtained by plotting $(a h v)^{2}$ as a function of $h v$ [33. The band gap energy of bulk CZTS was reported to be $1.45 \mathrm{eV}$ [41]. The band gaps of the assynthesized CZTS sample and that annealed at temperatures of 450,500 and $550^{\circ} \mathrm{C}$ were found to be $1.79,1.64,1.55$ and $1.44 \mathrm{eV}$, respectively. It is known that $E_{g, \text { nano }}$ - the band gap energy of semiconductor nanocrystals - increases with decrease in the particle size [42]:

$$
E_{g, \text { nano }}=E_{g, \text { bulk }}+\frac{\pi^{22}}{2 \mu D^{2}}-1.786 \frac{e^{2}}{4 \pi \varepsilon_{0} \varepsilon_{r} D} .
$$

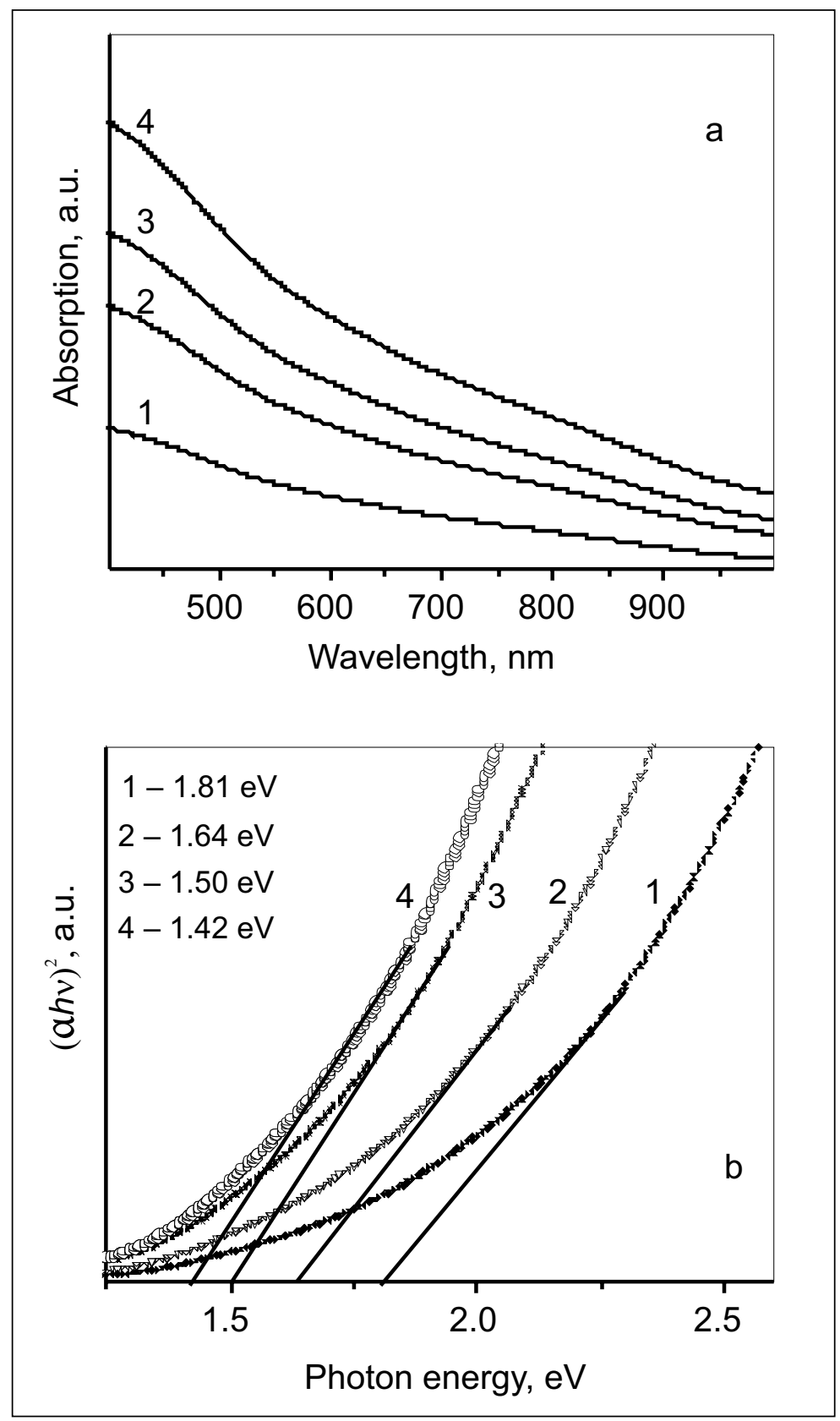

Fig. 9. (a) The UV-Vis absorption spectra of CZTS as-synthesized (1) and annealed at temperatures ( $\left.{ }^{\circ} \mathrm{C}\right)$ of: 450 (2), $500(3), 550(4)$; (b) plots $(\mathrm{ahu})^{2}$ as a function of the photon energy of as-deposited and annealed CZTS nanoparticles 
$E_{g, b u l k}$ is the band gap energy of bulk material, $\mu$ is the reduced mass of the electron-hole pair, $\mathrm{D}$ is the particle size. The increase in the band gap energy of a nanocrystalline semiconductor is

$$
\Delta E_{g}=E_{g, \text { nano }}-E_{g, b u l k}
$$

Figure 10 depicts the dependence of the increase in the band gap energy of nanocrystalline CTZS $\Delta E_{g}$ as a function of the crystallite size $\mathrm{D}$ : the theoretical dependence shows open square symbols values calculated from equations (1) and (2) using $\mu$ and $\varepsilon_{r}$ values from work [43]. For the experimental points, the $\mathrm{D}$ values were taken from Table 3 and $E_{g \text {,nano }}$ values were taken from Fig. 9b for the respective annealing temperature. The experimental data are in a rather good agreement with the theory. This result supports the suggestion that the dependence of CZTS nanoparticles band gap energy on the annealing temperature could be related with the crystallite size.

Figure 11 shows the response of the open-circuit potential $\left(E_{o c}\right)$ values of the as-synthesized and annealed at a temperature of $550^{\circ} \mathrm{C}$ sample 1 and the as-synthesized sample 2 deposited on the surface of ITO under illumination in a $0.5 \mathrm{M} \mathrm{Na}_{2} \mathrm{SO}_{4}$ solution. The positive shift of $E_{o c}$ under illumination indicates the presence of p-type conductivity in the CZTS samples. The increase in $E_{o c}$ values was considerably smaller for the as-synthesized sample as compared to that of the annealed one. This could be attributed to a lower degree of crystallinity and a larger band gap of the former.

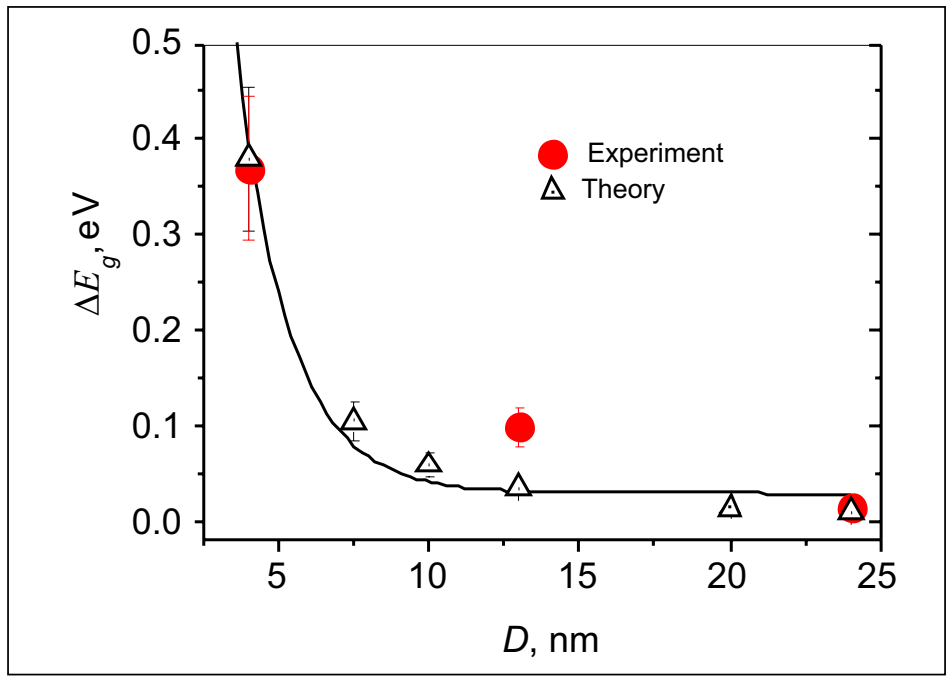

Fig. 10. Increase in the band gap $\Delta E_{g}$ of nanocrystalline CZTS as a function of the crystallite size: theory (an open square) and experiment (a filled circle)

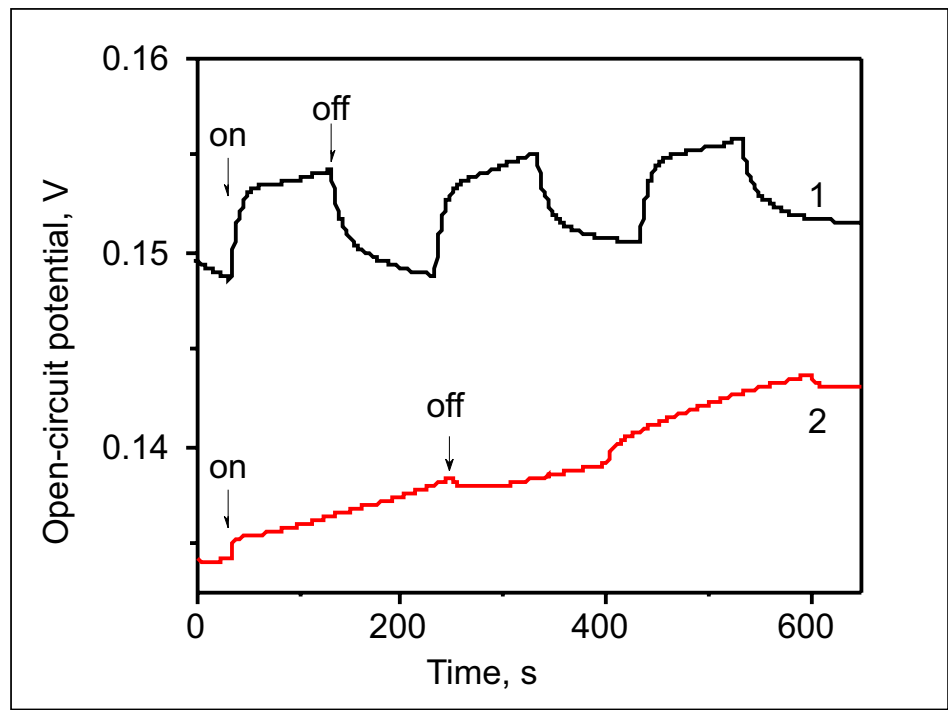

Fig. 11. Variation in the open-circuit potential of CZTS annealed at $550^{\circ} \mathrm{C}(1)$ and as-synthesized CZTS (2) deposited on the IT0 electrode under chopped illumination $\left.(\sim 100 \mathrm{~mW} \mathrm{~cm})^{-2}\right)$ in a $0.5 \mathrm{M} \mathrm{Na}_{2} \mathrm{SO}_{4}$ solution 


\section{CONCLUSIONS}

CZTS nanoparticles have been prepared by microwaveassisted heating irradiation. Both the reaction temperature and the duration of temperature increase have a profound effect on the chemical composition of CZTS nanoparticles. When the reaction temperature was $250^{\circ} \mathrm{C}$ and it was reached after $10 \mathrm{~min}$, the chemical composition was the closest to the $\mathrm{Cu}_{2} \mathrm{ZnSnS}_{4}$ stoichiometry. The annealing of as-synthesized CZTS nanoparticles at temperatures in the range from 400 to $550^{\circ} \mathrm{C}$ has yielded an increase in the crystallite size and purity of CZTS, but did not influence the grain size. The formation of nearly single phase CZTS was confirmed by XRD and Raman spectroscopy. The XRD in situ measurements showed that metastable hexagonal $\mathrm{ZnS}$ became undetectable by XRD at temperatures above $450^{\circ} \mathrm{C}$ and the phase of $\mathrm{Cu}_{2} \mathrm{SnS}_{3}$ fully transformed into the CZTS phase after $120 \mathrm{~min}$ of annealing at a temperature of $550^{\circ} \mathrm{C}$ in helium atmosphere. The photoelectrochemical studies have evidenced that the as-synthesized CZTS crystallites and those annealed at a temperature of $550^{\circ} \mathrm{C}$ exhibit p-type conductivity. The UV-Vis absorption spectra yielded the dependence of band gap energy on the postannealing temperature. The band gap energy of $1.44 \mathrm{eV}$ was obtained after annealing of the as-synthesized CZTS crystallites at a temperature of $550^{\circ} \mathrm{C}$. The band gap energy value decreased with the increase in the annealing temperature. The comparison of the band gap energy values and the crystallite size after the post-annealing of CZTS powder at respective temperatures suggests dependence of $E_{g}$ on the crystallite size, which was in a good agreement with the theoretical calculations.

\section{ACKNOWLEDGEMENTS}

The work was carried out within the project VP1-3.1-ŠMM08-K-01-009 that is partly supported by the National Programme "An Improvement of the Skills of Researchers" launched by the Lithuanian Ministry of Education and Science.

Received 18 December 2017 Accepted 9 January 2018

\section{References}

1. M. A. Green, K. Emery, Y. Hishikawa, W. Warta, Prog. Photovolt: Res. Appl., 19, 84 (2011).

2. H. Katagiri, K. Jimbo, W. Maw, et al. Thin Solid Films, 517, 2455 (2009).

3. D. Mitzi, O. Gunawan, T. Todorov, K. Wang, S. Guha, Sol. Energy Mater. Sol. Cells, 95, 1421 (2011).

4. T. K. Todorov, J. Tang, S. Bag, et al., Adv. Energy Mater., 3, 34 (2013).
5. W. Wang, M. T. Winkler, O. Gunawan, et al., Adv. Energy Mater., 4, 1301465 (2014).

6. D. A. R. Barkhouse, O. Gunawan, T. Gokmen, T. K. Todorov, D. B. Mitzi, Prog. Photovolt.: Res. Appl., 20, 6 (2012).

7. S. Ahmed, K. B. Reuter, O. Gunawan, L. Guo, L. T. Romankiw, H. Deligianni, Adv. Energy Mater., 2, 143508 (2012).

8. J.-O. Jeon, K. D. Lee, L. S. Oh, et al., ChemSusChem., 7, 1073 (2014).

9. F. Jiang, H. L. Shen, J. L. Jin, W. Wang, J. Electrochem. Soc., 159, H565 (2012).

10. H. Katagiri, K. Jimbo, S. Yamada, et al., Appl. Phys. Express, 1, 41201 (2008).

11. S. Oueslati, G. Brammertz, M. Buffičre, et al., Thin Solid Films, 582, 224 (2015).

12. N. Kamoun, H. Bouzouita, B. Rezig, Thin Solid Films, 515, 5949 (2007).

13. K. Maeda, K. Tanaka, Y. Fukui, H. Uchiki, Sol. Energy Mater. Sol. Cells, 95, 2855 (2011).

14. Q. J. Guo, G. Ford, W. Yang, et al., J. Am. Chem. Soc., 132, 17384 (2010).

15. Y. Wang, H. Gong, J. Alloys Comp., 509, 9627 (2011).

16. Y. L. Zhou, W. H. Zhou, Y. F. Du, M. Li, S. X. Wu, Mater. Lett., 65, 1535 (2011).

17. Y. Zhao, W. Tao, X. Chen, J. Liu, A. Wei, J. Mater. Sci.: Mater. Electron., 26, 5645 (2015).

18. B. Flynn, W. Wang, C.-H. Chang, G. S. Herman, Phys. Status Solidi A, 209, 2186 (2012).

19. G.-Q. Wang, P. Chen, C.-M. Tseng, CrystEngComm., 15, 9863 (2013).

20. S. W. Shin, J. H. Han, C. Y. Park, A. V. Moholkar, J. Y. Lee, J. H. Kim, J. Alloys Comp., 516, 96 (2012).

21. R. Saravana Kumar, B. D. Ryu, S. Chandramohan, J. K. Seol, S.-K. Lee, Ch.-H. Hong, Mater. Lett., 86, 174 (2012).

22. Y. Zhao, W. Tao, X. Chen, J. Liu, A. Wei, J. Mater. Sci.: Mater. Electron., 26, 5645 (2015).

23. W. Wang, H. Shen, X. He, Mater. Res. Bull., 48, 3140 (2013).

24. W. Wang, H. Shen, H. Yao, J. Li, J. Jiao, J. Mater. Sci.: Mater. Electron., 26, 1449 (2015).

25. R. Lydia, P. Sreedara Reddy, J. Nano- Electron. Phys., 3, 03017 (2013).

26. W. Wang, H. Shen, X. He, J. Li, J. Nanopart. Res., 16, 2437 (2014).

27. J. Chen, Q. Chen, H. Yuan, et al., J. Mater. Sci: Mater. Electron., 25, 873 (2014).

28. R. Ahmad, K. S. Nicholson, Q. Nawaz, W. Peukert, M. Distaso, J. Nanopart. Res., 19, 238 (2017).

29. R. Saravana Kumar, C.-H. Hong, M.-D. Kim, Advanc. Powder Technol., 25, 1554 (2014).

30. V. A. Madiraju, K. Taneja, M. Kumar, R. Seelaboyina, J. Mater. Sci.: Mater. Electron., 27, 3152 (2016).

31. Y.-H. Lin, S. Das, C.-Y. Yang, J.-Ch. Sung, C.-H. Lu, J. Alloys Comp., 632, 354 (2015).

32. T. Kobayashi, K. Jimbo, K. Tsuchida, S. Shinoda, T. Oyanagi, H. Katagiri, Jpn. J. Appl Phys., 44, 783 (2005).

33. K. Patel, D. Shah, V. Kheraj, J. Nano- Electron. Phys., 5, 02031 (2013). 
34. A. C. Ferrari, J. Roberston, Phys. Rev. B, 61, 14095 (2000).

35. M. G. Sousa, A. F. da Cunha, P. A. Fernandes, J. P. Texeira, R. A. Sousa, J. P. Letao, Sol. Energy Mater. Sol. Cells, 126, 101 (2014).

36. D. M. Berg, M. Arasimowicz, R. Djemour, et al., Thin Solid Films, 569, 113 (2014).

37. K. Patel, D. V. Shah, V. Kheraj, J. Alloys Comp., 622, 942 (2015).

38. B. Ananthoju, F. J. Sonia, A. Kushwaha, D. Bahadur, N. V. Medhekar, M. Aslam, Electrochim. Acta, 137, 154 (2014).

39. J. He, L. Sun, Y. Chen, J. Jiang, P. Yang, J. Chu, J. Power Sources, 273, 600 (2015).

40. M. Valdes, M. Modibedi, M. Mathe, T. Hillie, M. Vazquez, Electrochim. Acta, 128, 393 (2014).

41. J. J. Scragg, P. Dale, L. Peter, G. Zoppi, I. Forbes, Phys. Status Solidi B, 245, 1772 (2013).

42. H. Borchert, Energy Environ. Sci., 3, 1682 (2010).

43. C. Persson, J. Appl. Phys., 107, 053710 (2010).
Giedrė Grincienė, Vidas Pakštas, Raimondas Giraitis, Gediminas Niaura, Arnas Naujokaitis, Jurga Juodkazytė, Loreta Tamašauskaitė-Tamašiūnaitė, Remigijus Juškènas, Birutè Šimkūnaitè-Stanynienè, Eugenijus Norkus

\section{MIKROBANGŲ SINTEZĖS BŪDU PAGAMINTŲ CZTS NANODALELIŲ CHARAKTERIZAVIMAS}

\section{Santrauka}

$\mathrm{Cu}_{2} \mathrm{ZnSnS}_{4}$ (CZTS) nanodalelès, kurios gali būti naudojamos saulès celių absorberių sluoksniams gaminti, susintetintos naudojant mikrobangų reaktorių iš vario, cinko, alavo chloridinių tirpalu ir tiokarbamido. Darbe išnagrinèta CZTS nanodalelių sintezès reakcijos temperatūros, jos kèlimo greičio bei atkaitinimo ịtaka sintezės produktų cheminei sudèčiai, kristalinès struktūros parametrams, kesteritinès fazės grynumui ir optinèms savybėms.

Mikrobangų sintezès būdu susintetintų miltelių cheminè sudètis artimiausia $\mathrm{Cu}_{2} \mathrm{ZnSnS}_{4}$ stechiometrijai, kai reakcija vyksta $250^{\circ} \mathrm{C}$ temperatūroje, pasiektoje per $10 \mathrm{~min}$. Sintezès produktus atkaitinus $60 \mathrm{~min} .550^{\circ} \mathrm{C}$ temperatūroje, gauti kesteritinès struktūros CZTS milteliai, sudaryti iš sferinių nanodalelių 200-500 nm dydžio aglomeratų. RSD ir TEM analizès tyrimai patvirtina, kad CZTS nanodaleles sudaro apie $20 \mathrm{~nm}$ dydžio kristalitai.

Taikant RSD in situ metodą, patvirtintas CZTS kesteritinès struktūros susidarymo mechanizmas. Nustatyta, kad keliant temperatūrą iki $550^{\circ} \mathrm{C}$ priemaišinė $\mathrm{Cu}_{2} \mathrm{SnS}_{3}$ junginio fazè visiškai persikristalina ị CZTS fazę. Tai patvirtina ir atlikti Raman spektroskopijos tyrimai.

Danga, suformuota iš $550^{\circ} \mathrm{C}$ temperatūroje atkaitintų CZTS nanodalelių, pasižymi p-tipo laidumu. Keliant atkaitinimo temperatūrą CZTS kristalitai dideja, keičiasi ir junginio draustinès energijos juostos plotis $\left(E_{g}\right)$ nuo 1,44 iki iki 1,5 eV. 